

\title{
PADI: AUDIT ENERGI UNTUK SEMUA AKTIVITAS BUDIDAYA
}

\author{
Muhammad Iqbal Abdi Lubis \\ Renny Eka Putri \\ Andasuryani
}

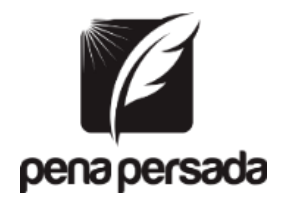

PENERBIT CV. PENA PERSADA 


\title{
PADI: AUDIT ENERGI UNTUK SEMUA AKTIVITAS BUDIDAYA
}

\author{
Penulis: \\ Muhammad Iqbal Abdi Lubis \\ Renny Eka Putri \\ Andasuryani
}

ISBN : 978-623-315-321-8

Design Cover :

Retnani Nur Briliant

Layout :

Eka Safitry

\section{Penerbit CV. Pena Persada}

Redaksi :

Jl. Gerilya No. 292 Purwokerto Selatan, Kab. Banyumas

Jawa Tengah

Email : penerbit.penapersada@gmail.com

Website : penapersada.com Phone : (0281) 7771388

\section{Anggota IKAPI}

All right reserved

Cetakan pertama : 2021

Hak Cipta dilindungi oleh undang-undang. Dilarang memperbanyak karya tulis ini dalam bentuk apapun tanpa izin penerbit 


\section{PRAKATA}

Assalamu'alaikum wa rahmatullahi wa barakatuh

Alhamdulillah wa syukurillah. Puji dan syukur penulis ucapkan kehadirat Allah SWT yang insyaa Allah senantiasa memberikan Rahmat dan Karunia-Nya. Shalawat dan salam mari sama-sama kita hadiahkan kepada Sayyidul Anbiya war-Rasul Muhammad Shallallahu 'alaihi wa sallam, sehingga penulis dapat menyelesaikan penulisan buku monograf ini. Buku ini merupakan bagian dari hasil penelitian kami yang berjudul "Studi Energi dan Ekonomi pada Budidaya Padi Sawah Berkelanjutan, Studi Kasus: Nagari Sungai Abang, Kecamatan Lubuk Alung" di bawah bimbingan Dr. Renny Eka Putri, S.TP, MP dan Dr. Andasuryani, S.TP, M.Si.

Penghargaan dan penghormatan penulis persembahkan kepada Ibunda, Istri, dan Adik-adik tercinta yang senantiasa mencurahkan do'a, kasih sayang, dan memberikan semangat selama penulisan buku ini. Especially karya ini penulis hadiahkan kepada Ayahanda tercinta yang telah mengarahkan untuk menyelesaikan studi hingga mampu menghantarkan pada profesi saat ini, semoga Allah jadikan amal jariyah bagi beliau. Aamiin

Penulis berharap, kiranya buku ini dapat bermanfaat bagi seluruh khalayak pembaca (akademisi dan non-akademisi). Penulis juga menyadari bahwa buku ini masih memiliki banyak kekurangan dan masih jauh dari kata sempurna. Kritik dan saran penulis harapkan untuk perbaikan kedepannya. Seterusnya, besar harapan kami agar kedepannya mampu lebih produktif dalam menulis buku dari hasil penelitian yang dilaksanakan.

Medan, Maret 2021

Tim Penulis 


\section{DAFTAR ISI}

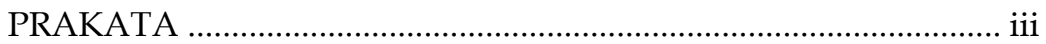

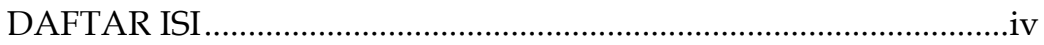

BAB I DASAR ENERGI PADA BUDIDAYA PADI .............................

BAB II KERANGKA TEORI ........................................................... 6

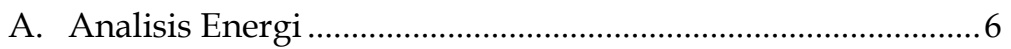

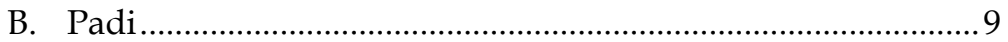

C. Budidaya Padi di Indonesia .................................................... 11

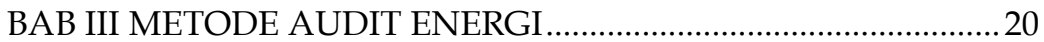

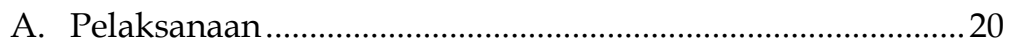

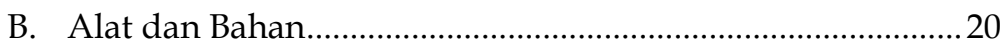

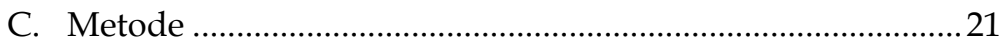

BAB IV GAMBARAN UMUM SITUASI LOKASI .............................33

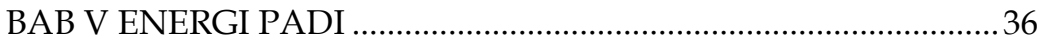

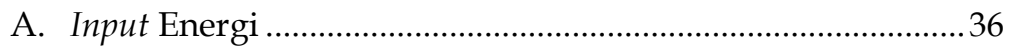

B. Distribusi Waktu Kerja ........................................................... 76

C. Analisis Output Energi ..............................................................77

D. Pemetaan Sistem Budidaya Padi ................................................78



F. Analisis Perbandingan Energi Manusia .................................. 81

G. Model Prediksi Hasil dan Validasi............................................... 85

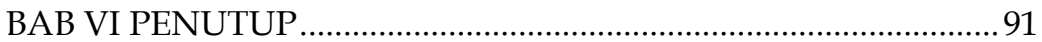

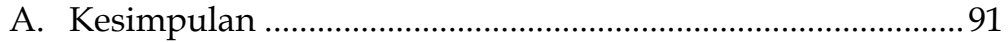

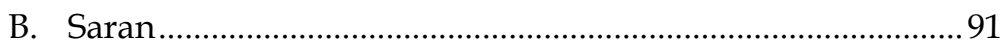

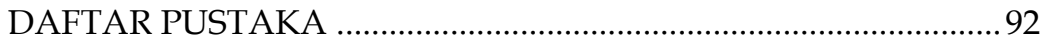

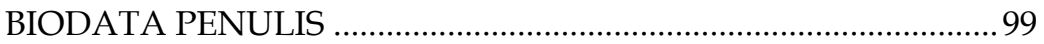




\section{BAB I \\ DASAR ENERGI PADA BUDIDAYA \\ PADI}

Berdasarkan data BPS (2018) jumlah penduduk Indonesia dengan usia > 15 tahun sebanyak 35.923.886 orang bekerja pada sektor pertanian di Tahun 2017 yang setara dengan 29,68\% dari jumlah seluruh penduduk Indonesia pada tahun 2018. Hal ini dapat mengidikasikan bahwa sektor pertanian masih masuk ke dalam salah satu kelompok sumber mata pencaharian tertinggi di Indonesia. Salah satu komoditi dari sektor pertanian yang ada di Indonesia adalah padi.

Padi merupakan salah satu tanaman pangan pokok bagi manusia, khususnya di Indonesia. Hampir seluruh daerah di Indonesia menitik-beratkan sumber asupan karbohidrat pada tanaman serealia ini. Hal ini selaras dengan pernyataan yang menyatakan bahwa hampir seluruh penduduk dunia bergantung pada tanaman padi sebagai bahan pangan utama (Lim et al., 2012), khususnya untuk daerah Asia (Chaicana et al., 2008).

Produktivitas dan produksi padi pada tahun 2015 masing-masing sebesar 5,34 ton.ha-1 dan 75.397.841 ton (BPS, 2017). Hal ini menunjukkan bahwa benar padi sebagai bahan pangan pokok di Indonesia. Berikutnya, BPS Sumbar (2018) mendata bahwa produktivitas, produksi, dan luas panen padi di Sumatera Barat tahun 2016 masing-masing 5,09 ton.ha-1, 2.503.452 ton, dan 491.875,70 ha. Kemudian, dari data tersebut menunjukkan data statistic yang bervariasi pada tiap kabupaten/kota di Sumatera Barat, salah satunya adalah Kabupaten Padang Pariaman. 
Kabupaten Padang pariaman yang terletak pada koordinat $0^{\circ} 11^{\prime \prime}-0^{\circ} 49^{\prime \prime} \mathrm{LS}$ dan $98^{\circ} 36^{\prime \prime}$ - 100 28' BT dengan luas wilayah $1.328,79 \mathrm{~km}^{2}$ memiliki sedikitnya 17 kecamatan dan salah satu diantaranya adalah Kecamatan Lubuk Alung. Kecamatan Lubuk Alung yang terdiri atas 9 nagari memiliki luas wilayah sebesar 11.163 ha. Sebanyak 3.139 ha dipergunakan sebagai lahan sawah dengan total produksi, luas panen, dan luas tanam secara berurutan adalah 51.037,30 ton; 9.413,50 ha; dan 9.669 ha. Sebagai salah satu kecamatan yang menjadi sentra produksi padi di Sumatera Barat, didukung oleh nagari potensial produksi padi dengan akses yang mudah menuju ibukota propinsi, kabupaten, dan kecamatan.

Penerapan teknologi usaha tani merupakan upaya yang digunakan untuk meningkatkan produksi apdi (Wangke et al., 2011). Penggunaan energi sebagai usaha memaksimalkan produksi dan meminimalisir penggunaan tenaga manusia adalah penerapan teknologi usaha tani yang semakin masif (Esengun et al., 2007). Penerapan energi secara efektif mampu menekan biaya, energi fosil, polusi, dan mencapai pertanian berkelanjutan (Uhlin, 1998).

Pertanian berkelanjutan dianulir mampu menekan impor pangan (terutama beras) sebagai jalan untuk mencapai kemandirian, kedaulatan, dan ketahanan pangan. Menurut Piringer dan Steinberg (2006) mendeklarasikan bahwa penerapan manjemen peningkatan produksi merupakan sebagai usaha untuk mencapai pertanian berkelanjutan yang mampu menekan biaya produksi, efisiensi sumber daya manusia, menjaga lingkungna, dan beberapa faktor input lain. Zangeneh et al. (2010) membagi beberapa faktor input yang dimaksud adalah yang membutuhkan biaya (memiliki nilai jual) dimulai dari proses produksi hingga pengangkutan.

Salah satu langkah yang dapat dilakukan untuk meningkatkan efisiensi energi selama proses produksi padi adalah dengan melakukan penghitungan/kajian/audit kebutuhan energi. Adapun usaha tersebut diantaranya adalah 
penjadwalan kegiatan, estimasi waktu kegiatan, jumlah tenaga kerja, jumlah alsintan (alat mesin pertanian), serta berbagai sarana yang diperlukan seperti bibit, bahan kimia/pestisida, pupuk, dan lain-lain (Purwantana, 2011). Penghitungan energi dapat dilaksanakna dengan mencatat seluruh kegiatan, mulai dari konsumsi bahan bakar dan waktu yang dihabiskan untuk setiap kegiatan.

Berbagai penelitian efisiensi penggunaan energi dan analisis ekonomi sudah banyak dilakukan pada beberapa komoditi pertanian (Muazu et al., 2015). Rahmat (2015) menjelaskan bahwa dalam hal evaluasi pemanfaatan energi, usaha penghematan penggunaan energi, dan rekomendasi untuk meningkatkan efisiensi penggunaan energi yakni dengan cara audit energi. Berbagai audit energi yang telah dilakukan pada beberapa komoditi pertanian adalah audit energi pada tanaman kentang di Provinsi Hamadan-Iran (Zangeneh et al., 2010), tanaman mentimun di Iran (Mohammadi dan Omid, 2010), tanaman tomat di Turki (Ozkan et al., 2011), serta tanaman padi di Malaysia (BockariGevao et al., 2005 dan Muazu et al., 2015).

Beberapa penelitian audit energi sebelumnya telah melakukan perhitungan energi tenaga kerja hanya dengan menerapkan nilai energi ekivalen (konversi energi). Hal ini diduga akan menghasilkan nilai yang kurang akurat, karena aka nada banyak factor yang mempengaruhi energi yang dilepaskan dari seorang pekerja. Beberapa faktor yang mempengaruhi diantaranya adalah usia, jenis kelamin, massa (bobot) tubuh, dan lain sebagainya. Mengatasi hal tersebut, pada penelitian ini peneliti mengukur energi yang dikeluarkan manusia menggunakan alat berupa smart watch yang mengukur denyut nadi dan energi yang dikeluarkan oleh pekerja secara real-time yang lebih tepat dan akurat.

Berdasarkan uraian di atas penulis melakukan penelitian dengan judul Studi Energi dan Ekonomi pada Budidaya Padi Sawah Berkelanjutan, Studi Kasus: Nagari Sungai Abang, Kecamatan Lubuk Alung, yang diharapkan 
akan melahirkan manfaat berupa informasi data total energi yang dibutuhkan untuk budidaya padi, kemudian menjadi rekomendasi data bagi Pemerintah Kabupaten Padang Pariaman untuk menyeimbangkan antara input dan output energi, serta menjadikan budidaya padi di Nagari Sungai Abang sebagai sawah percontohan precision farming (pertanian presisi) di Sumatera Barat. Hal ini dikarenakan beberapa hal, diantaranya adalah:

1. Studi energi merupakan suatu metode yang tepat untuk mengetahui konsumsi sumber energi (yang memerlukan biaya) yang dikeluarkan pada tiap kegiatan budidaya pertanian, sehingga mengurangi mubazir penggunaan energi.

2. Perlu dilakukan identifikasi jumlah energi yang dibutuhkan untuk tiap kegiatan budidaya padi di Nagari Sungai Abang, Kecamatan Lubuk Alung.

3. Perlu dilakukan penghitungan biaya produksi untuk tiap kegiatan budidaya padi di Nagari Sungai Abang.

4. Pengembangan metode yang dilaksanakan pada penelitian ini adalah dengan menggunakan alat ukur langsung (realtime) yaitu Garmin Forerunner 35 dan Heart Rate Monitor (HRM) untuk mengukur energi manusia.

Berdasarkan uraian di atas, secara umum memiliki tujuan untuk melakukan analisis kebutuhan sumber energi yang mengeluarkan biaya pada tiap kegiatan budidaya padi di Nagari Sungai Abang dari mulai pengolahan tanah hingga panen. Berikutnya, tujuan khusus dari penelitian ini yakni: (1) Analisis input energi pada tiap kegiatan budidaya padi, yang dikaji pada enam aspek, meliputi: manusia, bahan bakar, mesin, bibit, pupuk, dan pestisida; (2) Membandingkan nilai kebutuhan energi manusia yang dilakukan secara real-time menggunakan smart watch garmin forerunner 35 dan perhitungan yang menggunakan tabel konversi energi; dan (3) Membangun model prediksi hasil pada budidaya padi sawah. 
Sebelum penelitian ini dilakukan ditarik beberapa hipotesis yang akan meudahkan peneliti untuk menarik kesimpulan-kesimpulan dari hasil penelitian yang diperoleh. Diantaranya adalah: (1) Masing-masing variabel bebas (sumber input energi) secara simultan (bersama-sama) tidak berpengaruh signifikan terhadap variabel terikat (hasil padi) $\left(\mathrm{h}_{0}\right)$ dan masing-masing variabel bebas (sumber input energi) secara simultan berpengaruh signifikan terhadap variabel terikat (hasil padi) $\left(h_{1}\right)$; (2) Antara metode penghitungan kebutuhan energi secara real-time menggunakan alat dan penghitungan menggunakan tabel konversi berbeda nyata $\left(h_{0}\right)$ dan antara metode perhitungan kebutuhan energi secara real-time menggunakan alat dan penghitungan menggunakan tabel konversi tidak berbeda nyata $\left(h_{1}\right)$; dan (3)Energi terbesar yang digunakan adalah dengan penerapan alsintan dibandingkan dengan energi manusia $\left(\mathrm{h}_{0}\right)$ dan energi terbesar yang digunakan adalah dengan penerapan energi manusia dibandingkan dengan energi alsintan $\left(h_{1}\right)$. 


\section{BAB II \\ KERANGKA TEORI}

\section{A. Analisis Energi}

Energi dalam kegiatan pertanian adalah input penting berupa sumber tenaga (power source) seperti mesin, bahan bakar, listrik, bibit, bahan kimia (pestisida), pupuk, dan lain sebagainya. Output energi dalam sistem pertanian konvensional dan modern dipengaruhi oleh input energi yang diberikan. Penggunaan sarana produksi pertanian dan energi fosil secara intensif berdampak pada peningkatan produksi pertanian (Hatirli et al., 2006). Berbagai audit energi pada budidaya padi di berbagai negara dapat dilihat pada Tabel 1 .

Berdasarkan audit energi yang telah dilaksanakan para peneliti terdahulu, rasio energi dapat diartikan sebagai keuntungan (Muazu et al., 2015). Nilai rasio energi dipengaruhi oleh input energi yang diberikan, dimana semakin besar nilai input energi akan menurunkan nilai rasio energi. Input energi yang besar diartikan sebagai kelebihan input energi. Dalgaard et al. (2001) menjelaskan bahwa kebijakan pertanian saat ini telah mengembangkan sistem produksi pertanian yang memerlukan input energi fosil minimum untuk meningkatkan hasil dan mengatasi kelebihan input energi. Bockari-Gevao et al. (2005) menguatkan bahwa produktivitas pertanian tidak dapat diharapkan peningkatannya jika input energi seperti sumber tenaga (power source), kualitas bibit, pupuk, dan air irigasi tidak memadai. Peningkatan populasi dunia membutuhkan rencana yang efektif dalam konsumsi energi. Teknik dan metode yang efisien merupakan salah satu cara optimalisasi konsumsi energi dalam bidang pertanian. Kaltsas et al. (2007) mengemukakan bahwa analisis energi sebagai salah satu cara untuk menurunkan input energi tanpa mengurangi produksi pertanian dan keuntungannya. 
Tabel 1 Audit Input Energi pada Bidang Pertanian

\begin{tabular}{|c|c|c|c|c|}
\hline Produk/Daerah & $\begin{array}{l}\text { Energi Input } \\
\text { (MJ/ha) }\end{array}$ & $\begin{array}{l}\text { Energi } \\
\text { Output } \\
\text { (MJ/ha) }\end{array}$ & $\begin{array}{l}\text { Rasio } \\
\text { Energi }\end{array}$ & Referensi \\
\hline $\begin{array}{l}\text { Padi/Utara } \\
\text { Thailand }\end{array}$ & $\begin{array}{l}\mathrm{TE}=22.425,25 \\
\mathrm{FTE}=5.956,00 \\
\mathrm{ME}=9.444,38 \\
\mathrm{FE}=4.330,56 \\
\mathrm{HE}=1.188,31 \\
\mathrm{SE}=1.234,81 \\
\mathrm{PE}=271,19\end{array}$ & $57.537,64$ & 2,57 & $\begin{array}{l}\text { Chaichana } \\
\text { et al. (2008) }\end{array}$ \\
\hline $\begin{array}{l}\text { Padi/Dataran } \\
\text { Rendah, Malaysia }\end{array}$ & $\begin{array}{l}\text { TE }=12.225,97 \\
\mathrm{FTE}=7.721,03 \\
\mathrm{ME}=848,95 \\
\mathrm{FE}=2.717,82 \\
\mathrm{HE}=28,91 \\
\mathrm{SE}=837,00 \\
\mathrm{PE}=72,27\end{array}$ & $108.321,75$ & 8,86 & $\begin{array}{l}\text { Bockari- } \\
\text { gevao et al. } \\
(2005)\end{array}$ \\
\hline $\begin{array}{l}\text { Padi/Lahan } \\
\text { Basah, Malaysia }\end{array}$ & $\begin{array}{l}\mathrm{TE}=16.440,00 \\
\mathrm{FTE}=9.931,00 \\
\mathrm{ME}=478,00 \\
\mathrm{FE}=2.829,00 \\
\mathrm{HE}=42,00 \\
\mathrm{SE}=2.493,00 \\
\mathrm{PE}=667,00\end{array}$ & $127.574,40$ & 7,76 & $\begin{array}{l}\text { Muazu et al. } \\
\text { (2015) }\end{array}$ \\
\hline Padi/China & $\begin{array}{l}\mathrm{TE}=18.925,17 \\
\mathrm{FTE}=10.813,90 \\
\mathrm{ME}=1.492,02 \\
\mathrm{FE}=3.484,23 \\
\mathrm{HE}=- \\
\mathrm{SE}=2.021,39 \\
\mathrm{PE}=1.113,90\end{array}$ & $100.091,64$ & 5,29 & $\begin{array}{l}\text { Dazhong } \\
\text { dan } \\
\text { Pimentel } \\
(1984)\end{array}$ \\
\hline Padi/Thailand & $\begin{array}{l}\text { TE }=2.040,80 \\
\mathrm{FTE}=9.334,70 \\
\mathrm{ME}=3.062,20 \\
\mathrm{FE}=4.760,00 \\
\mathrm{HE}=24,10 \\
\mathrm{SE}=2.637,10 \\
\mathrm{PE}=652,70\end{array}$ & $81.308,20$ & 4,00 & $\begin{array}{l}\text { Chamsing, } \\
\text { Salokhe dan } \\
\text { Singh (2006) }\end{array}$ \\
\hline Padi/India & $\begin{array}{l}\mathrm{TE}=9.193,80 \\
\mathrm{FTE}=2.694,40 \\
\mathrm{ME}=360,80 \\
\mathrm{FE}=2.694,40 \\
\mathrm{HE}=2.291,30 \\
\mathrm{SE}=1.152,90 \\
\mathrm{PE}=-\end{array}$ & $39.673,83$ & 4,32 & $\begin{array}{l}\text { Chauhan, } \\
\text { Mohapatra } \\
\text { dan Pandey } \\
(2006)\end{array}$ \\
\hline Padi/Philipina & $\begin{array}{l}\text { TE }=14.237,55 \\
\mathrm{FTE}=9.279,96 \\
\mathrm{ME}=339,13 \\
\mathrm{FE}=2.218,50 \\
\mathrm{HE}=767,73 \\
\mathrm{SE}=1.004,83 \\
\mathrm{PE}=627,39\end{array}$ & $51.817,50$ & 3,64 & $\begin{array}{l}\text { Mendoza } \\
(2015)\end{array}$ \\
\hline
\end{tabular}

Keterangan: TE (total energi), FTE (energi pupuk), ME (energi mesin), FE (energi bahan bakar), HE (energi manusia), SE (energi bibit), dan PE (energi pestisida). 
Analisis energi sering dipakai untuk menggambarkan dimana, kapan, kenapa, dan bagaimana energi digunakan untuk meningkatkan kinerja dalam meningkatkan produksi, menurunkan biaya produksi, dan menurukan emisi gas rumah kaca yang berdampak pada perubahan cuaca. Analisis energi sangat bermanfaat dalam membantu mengidentifikasi kehilangan energi yang digunakan dan menggambarkan persentasi energi dalam bentuk segmentasi gabungan energi langsung dan tidak langsung (direct and indirect); terbarukan dan tidak tebarukan (renewable and non-renewable); serta bernilai jual dan tidak bernilai jual (commercial and noncommercial) yang dimanfaatkan dalam sistem produksi pertanian (Muazu et al., 2015). Energi langsung adalah sejumlah energi yang anda bakar sendiri, sedangkan energi tidak langsung adalah wadah yang anda gunakan untuk menghasilkan produk (Engel, 2018). Pada penelitian ini energi langsung adalah energi manusia dan energi tidak langsung adalah energi alsintan, bahan bakar, bibit, pupuk, dan pestisida. Selanjutnya, Kaltsas et al. (2007) berkeyakinan bahwa kombinasi antara analisis energi dan analisis ekonomi, seperti pada pertanian zaitun organik ataupun konvensional di Thasos Island yang akan sangat bermanfaat dalam mengevaluasi situasi saat ini dan mampu memutuskan strategi terbaik.

Purwantana (2011) memaparkan bahwa usaha meningkatkan efisiensi energi pada produksi padi yaitu dengan melaksanakan penghitungan/kajian kebutuhan energi. Usaha ini mencakup penjadwalan kegiatan, estimasi waktu tiap kegiatan, jumlah tenaga kerja, jumlah alat dan mesin pertanian (alsintan), dan seluruh sarana yang digunakan (bibit, pupuk, obat, air irigasi, dan lain-lain). Penghitungan energi dapat dilakukan dengan merekam seluruh kegiatan, mulai dari konsumsi bahan bakar dan waktu yang dihabiskan untuk setiap kegiatan. Berikutnya dapat dilakukan penghitungan energi yang mengacu pada Tabel 2 sebagai nilai konversi input-output energi. 
Tabel 2 Nilai Konversi Energi Ekivalen Proses Produksi

\section{Padi}

\begin{tabular}{|c|c|c|c|}
\hline Item & Unit & $\begin{array}{l}\text { Energi } \\
\text { Ekivalen } \\
\text { (MJ/unit) }\end{array}$ & Referensi \\
\hline Benih Padi (Gabah) & $\mathrm{kg}$ & 16,74 & Muazu (2015) \\
\hline $\begin{array}{l}\text { Pupuk } \\
\text { Nitrogen (N) } \\
\text { Posfor (P) } \\
\text { Kalium (K) } \\
\text { Sulfur (S) } \\
\text { Seng/Zinkum (Zn) }\end{array}$ & $\begin{array}{l}\mathrm{kg} \\
\mathrm{kg} \\
\mathrm{kg} \\
\mathrm{kg} \\
\mathrm{kg}\end{array}$ & $\begin{array}{c}63,51 \\
13,99 \\
11,15 \\
9,23 \\
5,3\end{array}$ & $\begin{array}{c}\text { Purwantana (2011) } \\
\text { Purwantana (2011) } \\
\text { Rahman dan Hasan } \\
(2014) \\
\text { FAO (2001) } \\
\text { FAO (2001) }\end{array}$ \\
\hline $\begin{array}{l}\text { Obat } \\
\text { Herbisida } \\
\text { Fungisida } \\
\text { Insektisida }\end{array}$ & $\begin{array}{l}\mathrm{kg} \\
\mathrm{kg} \\
\mathrm{kg}\end{array}$ & $\begin{array}{l}288,00 \\
196,00 \\
237,00\end{array}$ & $\begin{array}{l}\text { Purwantana (2011) } \\
\text { Purwantana (2011) } \\
\text { Purwantana (2011) }\end{array}$ \\
\hline $\begin{array}{l}\text { Tenaga } \\
\text { Manusia, olah tanah } \\
\text { Manusia, non olah tanah } \\
\text { Solar } \\
\quad \text { Bensin } \\
\end{array}$ & $\begin{array}{l}\text { jam } \\
\text { jam } \\
\text { liter } \\
\text { liter }\end{array}$ & $\begin{array}{r}1,57 \\
0,79 \\
47,30 \\
42,30 \\
\end{array}$ & $\begin{array}{l}\text { Purwantana (2011) } \\
\text { Purwantana (2011) } \\
\text { Purwantana (2011) } \\
\text { Purwantana (2011) }\end{array}$ \\
\hline $\begin{array}{l}\text { Alsintan } \\
\text { Traktor } \\
\text { Alat Pertanian Lainnya }\end{array}$ & $\begin{array}{l}\mathrm{kg} \\
\mathrm{kg}\end{array}$ & $\begin{array}{r}93,61 \\
62,7 \\
\end{array}$ & $\begin{array}{l}\text { Muazu (2015) } \\
\text { Muazu (2015) }\end{array}$ \\
\hline $\begin{array}{c}\text { Lain-lain } \\
\text { Beras }\end{array}$ & $\mathrm{kg}$ & 15,48 & Purwantana (2011) \\
\hline
\end{tabular}

\section{B. Padi}

Padi (Oryza sativa L.) adalah tanaman semusim dengan morfologi batang berongga dan bulat yang biasa disebut jerami, daun memanjang dengan ruas searah dengan batang daun (Gambar 1). Batang utama dan anakan membentuk rumpun pada fase vegetatif dan membentuk malai pada fase generatif. Air dibutuhkan tanaman padi untuk pembentukan karbohidrat pada daun, menjaga hidrasi protoplasma, pengangkutan dan mentranslokasikan makanan serta unsur hara dan mineral. Air sangat dibutuhkan untuk perkecambahan biji. Pengisapan air merupakan kebutuhan biji untuk berlangsungnya kegiatan-kegiatan di dalam biji (Kartasapoetra, 1988). 


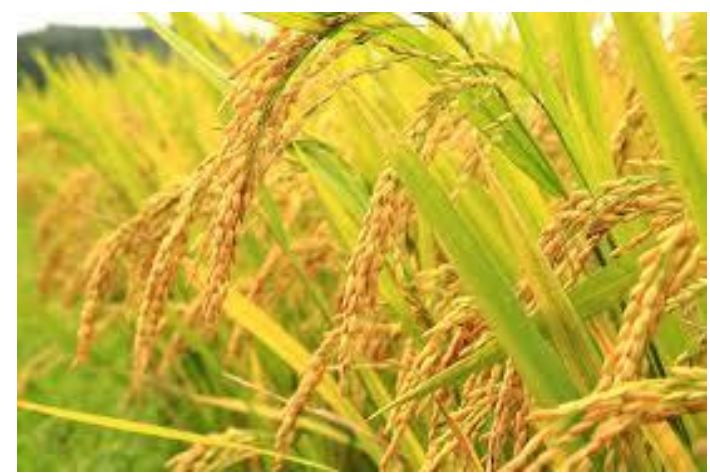

Gambar 1 Padi (Oryza sativa L.)

Nahar (1994) menambahkan bahwa padi adalah golongan dari famili rumputan (Gramineae) genus Oryza memiliki sedikitnya 21 spesies, dua diantaranya adalah Oryza Sativa L. dan O. glaberrima Steud. Padi varietas O. glaberrima Steud. umumnya dibudidayakan di Afrika dan terbatas produksinya di Afrika Barat. Virmani dan Ilyas-Ahmed (2007) memaparkan bahwa padi (Oryza sativa L.) sejak 8000 tahun lalu telah dibudidayakan di Cina Selatan dan Timur Laut India. Saat ini padi telah dibudidayakan di berbagai negara, diantaranya: 30 di Asia, 28 di Amerika, 41 di Afrika, 11 di Eropa, dan 4 di Oceana, dari total 193 negara di dunia.

Ferrero dan Tinarelli (2008) menguatkan bahwa padi merupakan tanaman yang tumbuh dan dikonsumsi oleh setiap orang di dunia karena kemampuan yang dapat tumbuh pada kondisi iklim dan tanah yang berbeda. Padi adalah salah satu tanaman pangan yang paling banyak dibudidayakan, selain itu hanya gandum yang mencukupi dalam volume produksi. Selanjutnya Khan et al. (2009) menyatakan bahwa lebih dari setengah populasi penduduk dunia menjadikan padi sebagai tanaman pangan pokok. Padi sebagai tanaman pangan pokok tidak serta merta dapat langsung dikonsumsi. Hasil olahan yang biasa dijadikan bahan pangan oleh masyarakat adalah padi dalam bentuk olahan, yang biasa disebut dengan nasi (bahan dasar: beras). Perlu proses kompleks yang harus dijalani untuk mendapatkan beras layak konsumsi. 
Beras yang merupakan turunan utama padi dan memegang peranan penting sebagai sumber pangan utama di dunia. IRRI (2006) merangkum bahwa permintaan terhadap beras meningkat dan telah diestimasikan dalam satu dekade kedepan (2005 - 2015) dengan konsumsi beras yang juga akan meningkat sebesar $50 \mathrm{Mt}$ dari $531 \mathrm{Mt}$ di tahun 2005 hingga $581 \mathrm{Mt}$ di tahun 2015. Lebih mendalam Kubo dan Purevdorj (1991) memprediksi bahwa konsumsi beras akan meningkat sebesar $873 \mathrm{Mt}$ atau 1,60 kali dari tahun 2000 hingga 2030 mendatang. Chaichana et al. (2008) menyatakan beras sebagai sumber daya utama yang dijadikan sandaran utama dalam menopang ketahanan pangan dibanyak Negara, misalnya di Asia. Nutrisi dari beras putih yang tidak mengalami pemolesan (polished) dengan kadar karbohidrat 71 hingga 77\% dan protein 5 hingga $8 \%$, beras merah mengandung vitamin pada tiap 100 gramnya, yakni: B1 (0,34 g); B2 (0,05 g); Asam Folat (20,00 g); Asam Titanic (1,50 g); dan Niacin (0,62 g).

\section{Budidaya Padi di Indonesia}

Indonesia merupakan negara dengan sumber mata pencaharian terbesar pada sektor pertanian. Salah satu komoditi pertanian yang dibudidayakan adalah padi. Menurut Sholeh (2011) manusia telah mengenal teknik budidaya padi sejak ribuan tahun yang lalu. Salah satu teknik budidaya yang cukup terkenal di Indonesia adalah budidaya padi sawah. Budidaya padi sawah diduga berasal dari daerah Tiongkok, tepatnya di lembah sungai Yang Tse. Selain budidaya padi sawah ada juga budidaya padi lahan kering, lahan rawa, gogo rancah, dan budidaya padi organik.

Secara garis besar IRRI (2018) membagi langkah budidaya padi kedalam tiga fase utama, yaitu fase sebelum tanam (pre-planting), pertumbuhan (growth), dan setelah panen (post-production). Berikutnya, pada fase pertumbuhan dibagi atas penanaman (planting operation), manajemen air (water management), pemupukan (fertilizing), penyiangan (weed management), serta pengendalian hama dan penyakit (pest and disease controlling). 


\section{Fase Sebelum Tanam (pre-planting)}

IRRI (2018) membagi fase sebelum tanam atas pemilihan varietas padi (rice varieties), pemilihan kualitas bibit (seed quality), penjadwalan tanam (crop calendar), dan pengolahan tanah (land preparation). Pengolahan tanah merupakan hal penting yang harus dilakukan sebelum penanaman. Akhir dari proses pengolahan tanah yang baik adalah bentuk permukaan tanah yang rata (Ferrero dan Tinarelli, 2008), membuat permukaan tanah remah, meningkatkan porositas di permukaan dan sub-tanah, memperbaiki aerasi, dekomposisi unsur organik, untuk memudahkan pertumbuhan akar (Yule dan Willcocks, 1996), menunjang efektifitas pengontrolan gulma, dan efisiensi penggunaan air selama musim tanam (IRRI, 2018). Pengolahan tanah terdiri atas pengolahan tanah pertama (primary tillage) dan pengolahan tanah kedua (secondary tillage) yang dapat dikerjakan baik dengan cara manual/tradisional (menggunakan cangkul dan tenaga hewan) dan atau dengan cara modern (menggunakan traktor) (Campbell, 1990).

\section{a. Pengolahan Tanah Pertama (Primary Tillage)}

Hal yang perlu diperhatikan dalam pengolahan tanah yakni membersihkan sawah dari jerami dan rumput liar serta membersihkan saluran air. Selanjutnya dilakukan perbaikan pematang sawah dan pencangkulan pada sudut petak sawah yang sukar dijangkau pada proses pembajakan (Sholeh, 2011). Pengolahan tanah pertama bertujuan untuk menggemburkan tanah dengan cara membaliknya, memberantas gulma, dan proses pembenaman bahan organik untuk mempermudah dekomposisi serta membentuk struktur lumpur dan lapisan kedap (Sukristiyonubowo et al., 2013). Pengolahan tanah pertama dilaksanakan pada awal musim tanam dan dibiarkan 2 - 3 hari sebelum dilaksanakan pengolahan 
tanah kedua (Sholeh, 2011). Pengolahan tanah dapat dilakukan dengan cara manual ataupun dengan teknologi berupa alat mesin pertanian (alsintan). Proses pembajakan harus disesuaikan terhadap kedalaman lapisan olah tanah, sehingga lapisan kedap air tidak bocor dan akumulasi dari lapisan mangan (Mn) atau aluminium (Al) tidak terangkat. Pada umumnya tanah dibajak dengan kedalaman $10-20 \mathrm{~cm}$ (Sukristiyonubowo et al., 2013).

\section{b. Pengolahan Tanah Kedua (Secondary Tillage)}

Menurut Sholeh (2011) pengolahan tanah kedua dilaksanakan 2 - 3 hari setelah pengolahan tanah pertama. Menambahkan (Sukristiyonubowo et al., 2013) pengolahan tanah kedua atau yang biasa disebut sebagai tahap penggaruan bertujuan untuk menghaluskan tanah, pelumpuran, perataan permukaan tanah agar level genangan air merata, dan memudahkan proses penanaman padi. Beberapa cara pengolahan tanah pada budidaya padi sawah akan ditampilkan pada Gambar 2.


\section{Gambar 2 Berbagai Cara Pengolahan Tanah}

\section{Operasi Tanam (Planting Operation)}

Ahmed (2006) menjelaskan bahwa operasi penanaman padi terbagi atas dua yakni penanaman langsung (broadcasting) dan metode transplanting (Gambar 3). Sukristiyonubowo et al. (2013) memaparkan metode penanaman broadcasting (tabur benih langsung/Tabela) 
dipraktekkan oleh petani karena sisa perakaran pada lahan belum bersih, biaya dan waktu yang dibutuhkan lebih minim, serta kurangnya tenaga kerja. Tabela adalah suatu sistem penanaman padi dimana benih padi disebar dilapangan seacara langsung yang dibagi atas sistem Tabela dengan tabur benih, Tabela sistem cicil dalam barisan berjarak $25 \mathrm{~cm}$, dan Tabela dengan sistem dalam rumpun berjarak $20 \mathrm{~cm} \times 20 \mathrm{~cm}$.

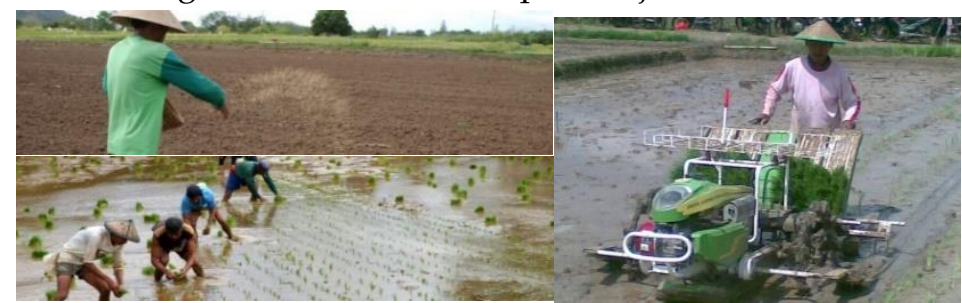

Gambar 3 Berbagai Metode Tanam

Menurut Oktaviana (2013) metode transplanting berbeda dengan metode sebelumnya. Pada metode ini tenaga kerja yang dibutuhkan lebih besar dibanding metode tradisional, sekitar $20 \%$ dari seluruh proses kegiatan budidaya tanaman padi. Selain membutuhkan tenaga kerja yang lebih banyak, metode ini juga memerlukan waktu yang lebih banyak. Selanjutnya dipertegas oleh Sukristiyonubowo et al. (2013) bahwa pada metode ini padi disemai terlebih dahulu hingga berkecambah dan bibit dipindahkan ketika berumur 18 - 25 hari. Pengoperasian metode transplanting dapat dilakukan manual menggunakan tangan atau dengan alat (rice transplanter). Selain itu, Kiple dan Ornelas (2000) berpendapat bahwa untuk 1 ha dibutuhkan 12 hingga 50 hari dari tenaga kerja. Namun, metode transplanting lebih baik dalam usaha pengontrolan hama, efisiensi pemakaian air lebih tinggi, keseragaman dalam tingkat kematangan lebih tinggi, produksi lebih tinggi dan pemanfaatan lahan secara maksimum dibandingkan dengan metode penanaman langsung (direct seeding methods). 


\section{Pemeliharaan dan Proteksi Tanaman (Crop Maintenance and Protection Operation)}

Pemeliharaan dan proteksii tanaman merupakan usaha yang dilaksanakan dengan tujuan untuk menunjang tumbuh kembang tanaman. Usaha yang dilakukan petani diantaranya adalah pemupukan, penyiangan, manajemen pengarian, serta pengendalian hama dan penyakit tanaman. Adapun penjelasan tiap kegiatan adalah sebagai berikut:

\section{a. Pemupukan (Fertilizing)}

Menurut Ferrero dan Tinarelli (2008) pemupukan bertujuan untuk memberikan nutrisi tambahan terhadap tanaman, akibat nutrisi tanaman oleh unsur hara tanah tidak tercukupi. Tanaman padi setidaknya membutuhkan 16 unsur hara untuk tumbuh efektif diantaranya adalah nitrogen, posfor, dan potasium sebagai unsur yang paling utama. Selanjutnya, Sholeh (2011) menambahkan bahwa pemupukan padi sawah dilakukan dua kali, yakni pada minggu 3 - 4 dan 6 - 8 setelah tanam. Jenis pupuk yang diberikan pada saat tanam adalah KCL dengan dosis $50 \mathrm{~kg} / \mathrm{ha}$. Pupuk lainnya adalah pupuk urea sebanyak $300 \mathrm{~kg} / \mathrm{ha}$ dengan cara disebar dan diinjak agar terbenam yang diberikan pada waktu sebelum penanaman. Khusus pupuk TSP sebanyak 75 - $175 \mathrm{~kg} /$ ha diberikan pada saat satu hari sebelum penanaman dan saat menjelang keluar malai.

Menurut Bockari-Gevao et al. (2005) pada beberapa skala pertanian yang berbeda di negara berkembang untuk pemupukan sangat popular menggunakan knapsack power blower, karena portable, murah, dan mudah dioperasikan. Namun, saat pendistribusian di lapangan sering terjadi penyumbatan pada blower akibat pupuk kental dan menggumpal. Sedangkan pada pertanian skala kecil dengan pendapatan rendah (low income) biasanya 